\title{
Islamic jurisprudence and the status of arthropods: as alternative source of protein and with regard to EI20
}

\begin{abstract}
Arthropoda being the biggest animal phylum of this planet is the fraternity of tiny living organisms. Their consumption has been a diverse subject amongst the various Islamic Schools. Maliki sect is the only school of thought that allows the eating of non-poisonous/hazardous arthropods other than locust which is held permitted by all the schools. After the emergence of halal food sector the question ascended to the faces of Islamic Scholars that either the food ingredients particularly E120 derived out of them would be rendered permissible or not. Even in the era where mankind has started realizing the insects as alternative sources of protein beyond the conventional food sources, the issue of their consumption becomes more relevant. Hence, this paper aims to explore the scope of their consumption with respect to the various rulings of different Islamic Schools of thought. Furthermore, it puts forth analytical discussion with a comprehensive conclusion paving a possible course for the halal industry players to adopt the Maliki view point. Numerous halal standards and conventional food regulations have also been unfolded to depict the legal status of arthropods particularly insects in different parts of the globe.
\end{abstract}

Keywords: halal, non-halal, arthropods, insects, protein, e120, consumption, islamic jurisprudence, schools of thought
Volume 6 Issue 4 - 2018

Syed Fazal ur Rahim

Islamic Food and Nutrition Council of America, Pakistan

Correspondence: Syed Fazal ur Rahim, Islamic Food and Nutrition Council of America (Pakistan), I44-A, Peoples Colony \#2, Faisalabad, Pakistan, Tel +92 3085694100 ,

Email fazalraheemI50@gmail.com

Received: June 13,2018| Published: July 13, 2018

\section{Introduction}

Consumption of food is the fundamental necessity of human beings. Their existence on the surface of the earth cannot be imagined without it. From the very ancient past to the present modern age, evolutionary process has happened in all treads of life but edibles remained more vibrant. Once when there was an era of caves and wildernesses, the dependence was upon grass and leaves. Today the foods industries are alluring all over the world. Food Science and Technology has become one of the major disciplines in the universities around the globe. Even a step towards future mankind has started thinking about his food beyond the conventional sources. Increasing population growth is estimated to reach at least 9billion by 2050 will result in additional demand for food globally. ${ }^{1}$ Conventional animal protein sources including beef, pork, and chicken meat may be deficient to encounter this need, subsequently opening a door to alternative sources. ${ }^{2}$ Edible insects demonstrate great potential as an environmentally friendly choice for future food demands. There are several beneficial aspects of utilizing insects as a sustainable food source including their high nutritional content. Besides fats and proteins, insects are also an excellent source of vitamins and minerals. ${ }^{3}$

A question persisted to be relevant in all these centuries, what to eat and what not to eat? Allah (SWT) answered the very question by declaring particular things halal and certain things haraam. Halal denotes permissibility and haraam connotes impermissibility. A Muslim leads his life in the domain of halal and keeps himself away from haraam. The universe is packed with living and non-living organisms, but everything is not allowed to be consumed. Cattle's meat and milk, non-toxic and non-intoxicated drinks and plants, fish with scales and non-predatory animals and birds fall in the slant of halal, while predatory animals and birds, toxic and intoxicated drinks and plants, pig, dead animals and blood categorized as haraam. ${ }^{4}$
The matter mounts to great concern when it is referred to the arthropods. Are they halal to consume? Particularly in the context of E120 and the fact that some insects like cricket and bee brood are being used as alternative source of protein. Cricket is rich in protein, low in fats and usually grinded to produce cricket flour, while bee brood particularly pupae though low in calcium but abundant in protein and carbohydrates and it is harvested by the beekeepers as food in many countries. $^{2}$ As per the carmine dye (E120), the outcome comprises of different narratives regarding the practices of halal standards based upon the opinions of various Schools of thought. Some of the halal standards permit carmine dye (E120) while some do not allow it, whereas the cricket flour or the edible insects as alternative source of protein have not been discoursed yet by the halal industry players. The United States Food and Drug Administration (FDA) and the European Commission's directives governing food additives in general and food dyes in particular promulgated specific instructions for the use of carmine dye but laid no clear guidelines for edible insects as they are new to the human food; hence they are treated like the other foods in the regulations and subjected as the subsidiary to sea creatures. ${ }^{5}$

In this paper the jurisprudential status of the consumption of arthropods with respect to its emerging status as alternative source of protein, the halal view of carmine dye (E120) and its uses in major industries will be discussed along with the United States Food and Drug Administration and European guidelines.

\section{Arthropods}

The taxon name ARTHROPODA was cited by VON SIEBOLD in $1848 .{ }^{6}$ Originally it is a Greek terminology. ARTHRO indicates jointed while PODA implies legs. Any animal that has more than four jointed legs is a member of this family. It is a huge phylum which includes eleven classes and every class has its own subclasses. 
Furthermore, it is divided in to two major forms, land and marine. They are basically invertebrate living organisms, such as insects, spiders, scorpions etc. Some of them, like mosquito and grasshopper enjoy a rich history with mankind. Together with human beings they can be found anywhere. They have been living in this Universe for millions of years. It is a belief that arthropod is the largest phylum and consists eighty five percent of the known animals. ${ }^{7}$ This fact is reflected by the following diagram (Figure 1).

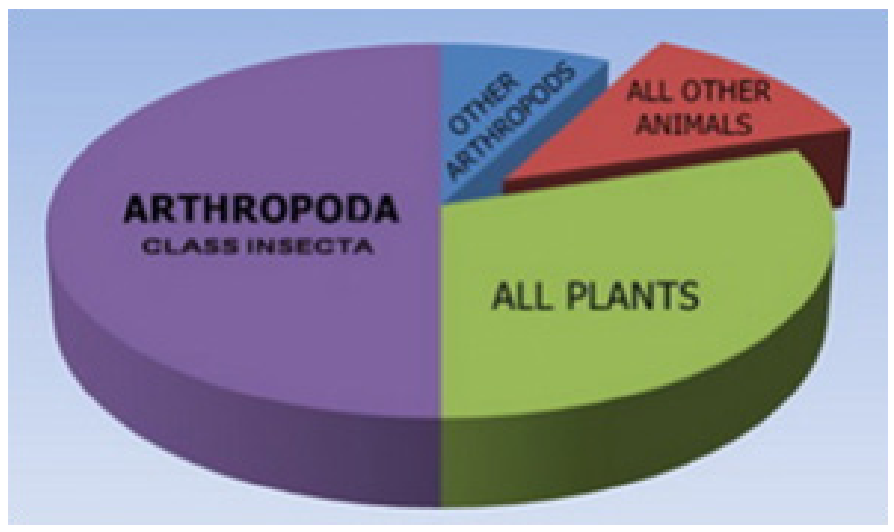

Figure I Diagram showing the majority of Arthropods in the universe. ${ }^{7}$

\section{A glance at arthropods}

It would be appropriate to have a glance at the ARTHROPODA phylum prior to elaborating on the technical aspects of the paper.

\section{Characters of arthropods}

Following are the major characters of arthropods.

a. Segmented body: It means that their bodies comprise of more than one part, like spiders have two parts and flies have three parts. This specialty discriminates them from the other living organisms.

b. Many jointed legs: Unlike the other animals, they have more and jointed legs. Spiders have eight legs while millipedes can have as many as hundreds. ${ }^{8}$

c. Exoskeleton: Like the armor of a soldier in the battle field, arthropods have the external skeleton, which prevents them from hardships. It is soft in the beginning as they born but hardens with the passage of time.

d. Invertebrate: Since arthropods are invertebrate animals, hence they don't have backbones.

e. Cold blooded: These animals are cold blooded. Therefore they depend upon the temperature of their environment.

f. Movement: This is one of the exiting features of arthropods. Unlike the other animals, they are capable to move on the different ranks. Not only can they fly, but creep and crawl as well.

g. Existing places: This feature also discriminates them from the other animals. They exist on the land, in the air and in the ponds and oceans. ${ }^{9}$ In simple, arthropods are interesting creatures with utmost distinctive features.

\section{Major classes of arthropods}

Following are the major classes of arthropods.

a. Insecta: This class includes countless numbers of insects such as beetle, mosquito, ant, butterfly etc. Their body structure is segmented, which contains head, thorax and abdomen. They have three pairs of legs and one pair of feeler. Usually the members of this group have wings but some wingless subclasses can also be found, like silverfish, springtail, bristletail etc. Whenever the word insect is heard, usually minds are polluted with the impression of detestation. The obvious nature of mankind considers them repulsive, but this is not the whole fact. The biological studies have unfolded the truth that there exist more than one million insect species in the world, among them are the numerous types of eye-catching subclasses, which are neither repulsive nor poisonous. Following are some of the examples. There are many other beautiful and attractive species of insects including SUNSET MOTH, BLUE DASHER, FLOWER MANTIS, HUMMINGBIRD MOTH, JEWEL BEETLE etc. Due to adequacy the exhibited examples are sufficient to prove the fact that all the insects are not detested (Figure 2-4). ${ }^{10-12}$

b. Crustacea: Crabs, lobsters, shrimps, barnacles and woodlice are the examples of this class. Usually their segmented bodies comprise of cephalothorax and abdomen, but some of them contain head and trunk. Cephalothorax implies fused head and thorax. They have five or more pairs of legs, two pairs of antennas and are wingless. ${ }^{13}$

c. MyriapodA: Millipedes and centipedes are among the members of this class. Their bodies consist of two segments, head and trunk. They have as many pairs of legs as one or two per trunk, one pair of antennae and are wingless. ${ }^{14}$

d. Archanida: This is the fourth major class of arthropods. Scorpion, king crabs, spiders, mites and ticks are the instances of this group. Their body structure incorporates of cephalothorax and abdomen. They have four pairs of legs. These animals do not have antennae and wings. ${ }^{15}$

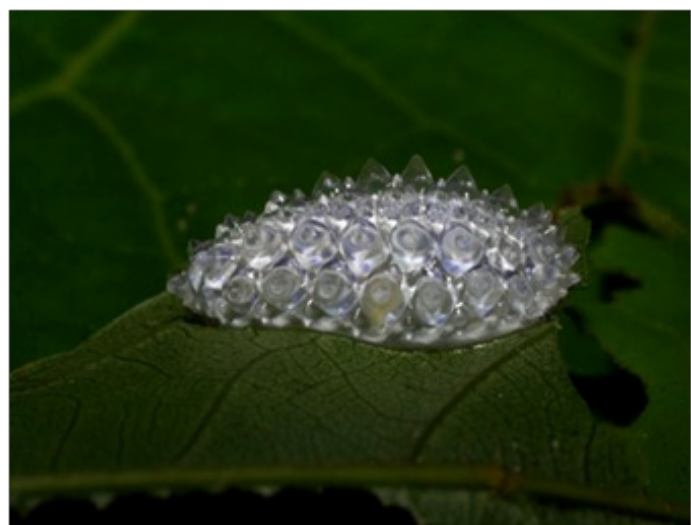

Figure 2 Jewel caterpillar. ${ }^{10}$ It looks like a precious jewel but is indeed a type of insect. The biologists could not disclose the matter that why this insect is so colorful, however they are of the view that these colors prevent them from predators. Usually it is found in Mexico. 


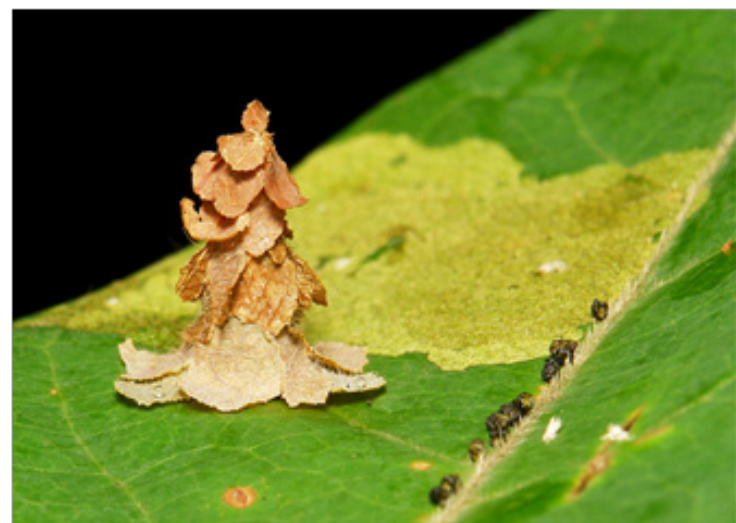

Figure 3 This insect is a member of butterfly family. One of the interesting features of these animals is the habit of making layers to hide themselves. They can be found anywhere in the world. ${ }^{12}$

In addition to the above four major classes, several minor classes are also found. The ONYCHOPHORA (velvet worms), TARDIGRADE (water bears), PENTASTOMIDA (tongue worms) and PYCNOGONIDA (sea spiders) are categorized as minor and finally a class of extinct arthropods, TRILOBITA (trilobites). They were recognized through the discovery of their fossils. They used to live in water several million years ago. ${ }^{9}$

As the truth has been outspread that ARTHROPODA is vastly expanded phylum and has a variety of animals, it is important to confess that there are numerous disgusted and repulsive animals among them which provide diversity to the universe, as Allah (SWT) did not create anything worthless. Yet this shall be against the divine innovative philosophy to declare the whole phylum or any of its major class repulsive due to the presence of some disgusted animals.

Following verse reflects the artistic skill of the Mighty God:

a. (Such is) the artistry of Allah, who perfected all things: for He is well acquainted with all that ye do. (Quran, 27:88). Furthermore, hedgehog belongs to Mammalia Class and its Family is ERINCIIDEA. It has been declared detested by the Prophet (PBUH). In this regard, following hadith must be taken in consideration.

b. Narrated Numaylah (RA), "I was with Ibn Umar, he was asked about eating hedgehog. He recited: "Say: I find not in the message received by me by inspiration any (meat) forbidden (aiming hedgehog to be lawful)." An old man who was with him said: I heard Abu Hurayrah says: It was mentioned to the Messenger of Allah

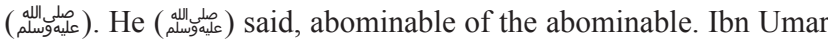
said: If the Messenger of Allah (aلdwade) had said it, it is as he said which we did not know". ${ }^{16}$

The mentioned hadith explicitly proclaims that hedgehog is detested. As stated, it belongs to Mammalia Class. Hereafter can the whole class be declared abominable due to its presence? No one will do this. Similar must be the case of insects and the other arthropods. How can a whole phylum or any of its class be deemed repulsive just because of the fact that there are some disgusted and abominable animals among them.

\section{Arthropods and Islamic jurisprudence}

Jurisprudence connotes study, knowledge and the science of law. ${ }^{17}$ After the adequate discussion on the characters and classes

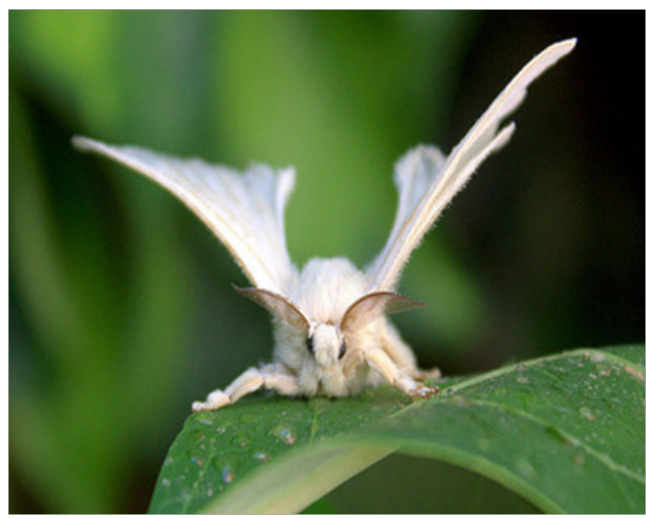

Figure 4 Silkmouth. These insects are the primary producers of silk and are domesticated. They depend upon human beings for their reproduction. They are found in Asia,Africa and America."

of arthropods the paper will zoom on the jurisprudential status of the consumption of arthropods. For this purpose it is necessary to understand the various classes of prohibition. Normally Pig, blood, dead animals, alcoholic drinks, predatory animals and birds are considered haraam as they have been explicitly mentioned in Quran and hadith. In this regard, whenever a prohibitory word is voiced, minds are enticed to the above stated apex category, having no idea regarding the following three stages of prohibition.

Makrooh-e-Tenzeehi: It means disliked slightly. This is not the degree of prohibition. A thing is not forbidden to be committed or consumed on this stage rather it is unsuitable, e.g. horse meat. According to Hanafi' School of thought, it is not appropriate to consume horse meet as it is dignified animal and used in war. Occasionally ingesting with left hand or without Tasmiah are the other examples. Furthermore, one who commits or consumes anything which falls in this category, shall be liable for nothing, neither for sin, nor for punishment.

Makrooh-e-Tehreemi: It means disliked bitterly. This is the degree of prohibition, but lesser in bitterness as compared with Haraam, e.g. eating something in the utensils made of gold, consumption of reproductive parts of halal animal being slaughtered in accordance with shariah principles and sale and purchase after the first call for Jumma' prayer. Moreover one who commits or consumes anything which is Makrooh-e-Tehreemi, shall be liable for sin.

Haraam: It means forbidden and disallowed absolutely. This is the apex degree of disallowance, e.g. murder, extortion, theft and adultery. Consumption of alcoholic drinks, pig, blood, dead and predatory animals and birds are the other examples of this category. One who commits or consumes anything which is Haraam, shall be liable for sin and punishment. Furthermore, one who intentionally refuses and rejects the prohibition of a matter declared Haraam by the definitive verse of Quran shall be deemed non-Muslim. ${ }^{17}$

The fact has now been explored that every prohibited thing must not be considered haraam (apex Category), it can be either Makroohe-Tenzeehi or Tehreemi. Normally when one Islamic School prohibits a thing for consumption or a matter for practice and the other school does not; it is rendered any of the mentioned categories of Makrooh by that other school. The matters related to apex category (Haraam) are unanimous among all the Sunni Schools of thought. In the light of this juristic discussion it is easy to understand the different juristic views of various Schools of thought on arthropods (Figure 5). ${ }^{18}$ 


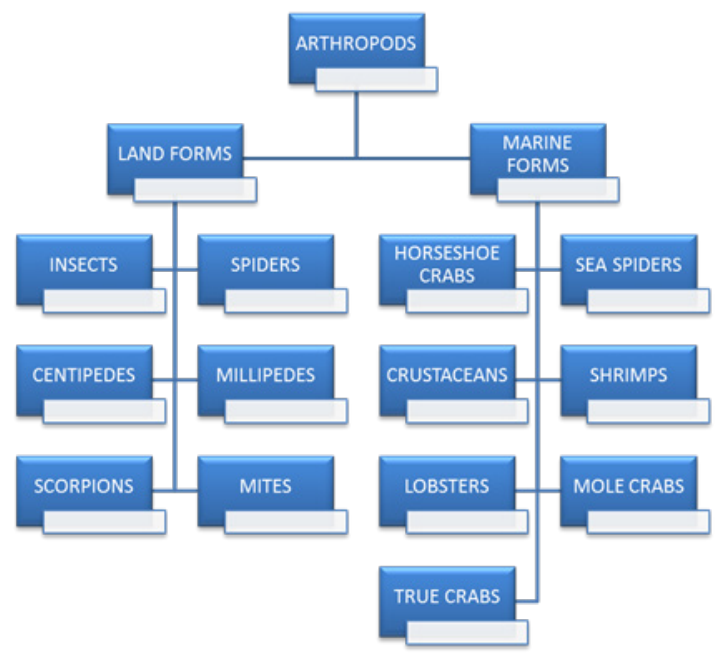

Figure 5 Classification of Arthropods. ${ }^{17}$

\section{Juristic opinions}

a. Hanafi, and Imamia Schools of thought are of the opinion that all the land form arthropods are non-halal and fall under the verse with the exception of locust. Furthermore, both the schools are of the view that amongst the marine forms, only shrimps are halal. ${ }^{18,19}$ Hanafi and Imamia Schools have the strictest opinions in this regard.

b. Hanbali School views that all the land form arthropods are non-halal with the exception of locust, whereas all the marine forms are halal. ${ }^{20}$

c. Shafi'I School of thought narrates that amongst the land forms the matter shall be referred to the consideration of human beings especially the customs of Arabs at the time of the Prophet (PBUH), Hence their viewpoint is not definitive in this regard. Since the custom of Arabs was not to consume insects and alike, therefore they decreed them non-halal, whereas about the marine forms, this school proclaims that all of them are Halal. ${ }^{20}$ Hanbali School in their second opinion has the same narrative.

d. Maliki school of thought views that all the non-poisonous/hazardous land and marine form arthropods are Halal to consume. ${ }^{21,22}$

e. It is important to know that Imam Shafi'I and Imam Ahmad legitimate the consumption of marine arthropods, whereas about land form they are close to Hanafi and Imamia Schools. Furthermore, Hanafi, Hanbali, Shafi'I and Imamia have erected their argument regarding land form arthropods on the following narrations. It is interesting that the hadiths on which these schools are instituting their arguments are not related to the arthropods. And makes lawful for them the good things and prohibits for them the evil.

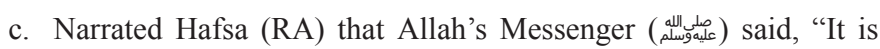
not sinful (of a Muhrim) to kill five kinds of animals, namely: the crow, the kite, the mouse, the scorpion and the rabid dog". ${ }^{23}$

d. Narrated 'Abdullah (RA) that while we were in the company of the Prophet ( (ل) a cave at Mina, when Surat-wal-Mursalat was revealed and he recited it and I heard it (directly) from his mouth as soon as he recited its revelation, Suddenly a snake sprang at us

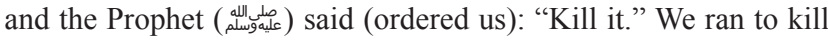

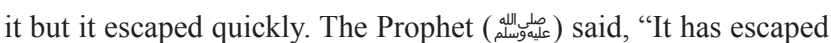
your evil and you too have escaped its evil". ${ }^{23}$

e. Narrated 'Aisha (RA) the wife of the Prophet that Allah's Messenger ( $)$ (ع) called the salamander a bad animal. ${ }^{23}$

f. Narrated Numaylah (RA), "I was with Ibn Umar, he was asked about eating hedgehog. He recited: "Say: I find not in the message received by me by inspiration any (meat) forbidden (aiming hedgehog to be lawful)." An old man who was with him said: I heard AbuHurayrah says: It was mentioned to the Messenger of Allah

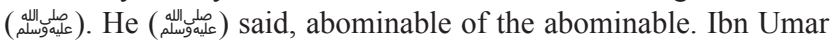

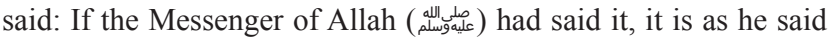
which we did not know". ${ }^{16}$

\section{Imam malik allows the consumption of non-poisonous, non-hazardous arthropods; the narrations on which he constructed his arguments are as under:}

a. Say, "I do not find within that which was revealed to me [anything] forbidden to one who would eat it unless it be a dead animal or blood spilled out or the flesh of swine-for indeed, it is impure-or it be [that slaughtered in] disobedience, dedicated to other than Allah . But whoever is forced [by necessity], neither desiring [it] nor transgressing [its limit], then indeed, your Lord is Forgiving and Merciful".

g. Narrated Milqam (RA) from his father that I accompanied the

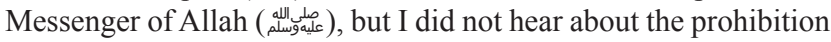
of (eating) insects and little creatures of land. ${ }^{16}$

h. Narrated Abdullah ibn Abbas (RA) that the people of pre-Islamic times used to eat some things and leave others alone, considering them unclean. Then Allah sent His Prophet (aلd (a) and sent down His Book, marking some things lawful and others unlawful; so what He made lawful is lawful, what he made unlawful is unlawful, and what he said nothing about is allowable. ${ }^{16}$

\section{Discussion}

The above verse (Quran, 7:157) states a ruling that impure, detested and abominable things are haraam to consume, but does not provide conclusive and exclusive details concerning repulsive living organisms. Thus the nature of this verse is deemed speculative in implication and interpretation, hereafter; it cannot be a source for apex category prohibition. ${ }^{17}$ However the jurists have deemed this verse definitive in case of blood, swine flesh, dead animals, alcoholic drinks, human and animal waste and the animals which naturally live on impure and abominable things, because some other verses and hadiths describe the same. Hence all the mentioned things shall be rendered haraam. The question ascends when arthropods are conversed under the scope of this verse. Are they impure and detested? Besides, being known to the fact that their phylum is the largest which contains almost eighty five percent of the known animals and incorporates the land and marine forms; do they come under the ruling of this verse?

Since it has been proven that there exist differences in the narratives of different Schools of thought as well as the hadiths allowing the consumption of arthropods and non-providence of conclusive details regarding repulsive animals, hence the above mentioned verse $(7: 157)$ shall be deemed speculative (Zanni-Ul-Dalalah) in nature with regard to the prohibition of ARTHROPODA phylum and however the matter is affirmed that the apex category (Haraam) can only be derived from 
definitive (Qat'I-Ul-Dalalah) verse. ${ }^{17}$ Moreover, being known to the fact that whoever intentionally refuses the prohibition of a matter declared Haraam (Apex category) by the definitive verse of Quran shall be deemed non-Muslim, hereafter one cannot expect from the jurists like Imam Malik, Imam Shafi'I and Imam Ahmad that they may have the opinions which are repugnant to the spirit of this verse (7:157), because Imam Malik deems all the non-hazardous arthropods halal while Imam Shafi'I and Imam Ahmad declare marine form halal Therefore; arthropods as a phylum shall not be adjudicated haraam (Apex Category) due to detestation in the context of mentioned verse unless fall under any other definitive verse or hadith, like blood, dead animals, pig carnivores etc. Yes, any of the members of this phylum can be declared non-halal on the basis of disliking.

Eight animals (salamander, mouse, kite, crow, hedgehog, dog, Scorpion and snake) have been deemed detested in the above mentioned four hadiths provided by Hanafi, Shafi'I and Hanbali Schools to support their narrative. Among them, only scorpion belongs to arthropods, which has been decreed non-halal because of its venomousness not due to detestation, while the rest are related to other phylum. Among the prohibited eight animals salamander, mouse and kite are carnivores while crow, hedgehog and dog are omnivores. Some zoologists have added the specific classes of mouse to omnivores while dog to carnivores. Hence all these animals have been professed haraam due to the fact that they prey on the other living creatures and predators are deemed haram due to the following definitive text of hadith: ${ }^{24}$

a. Ibn-e-Abbas (RA) reported that Allah's Messenger (PBUH) prohibited the eating of all fanged beasts of prey, and all the birds having talons.

Scorpion and snake are poisonous, thus they have been prohibited because of their venomousness. Already believers have been directed to stay away from any kind of destruction. Following verse states a ruling in this regard:

b. And do not throw (yourselves) by your (own) hands into destruction and do fair deeds; surely Allah loves the fair-doers (Quran, 2:195).

However among all of them the only arthropod is the scorpion. Will it be fair to render the whole phylum or any of its major class repulsive due to its presence?

\section{Doctrine of silence}

There are certain matters which are maximally defined by Islamic Jurisprudence, like oneness of Allah, last prophet hood of Prophet Muhammad (PBUH), prayers, fasting, Hajj, Zakat etc. Their primary and secondary issues have been enlightened. Whereas some matters are minimally described, their primary concerns have been discoursed but subsidiary have been left to the mankind, like clothing. ${ }^{25}$ Since it is one of the most important necessities of human beings, yet there exist no mandatory secondary descriptions in jurisprudence. However, what can be found primarily in this regard for men, are the prohibition of silk and covering the private parts of body and for women is covering the whole body. In addition to these injunctions, sensitivity of Islam shall also be taken in consideration and the decision of its compliance has been delegated to the mankind as jurisprudence is silent in the context of obligatory directions. Hence the Muslims of this planet while clothing according to their circumstances, customs, geographies, economic conditions, political conditions, wishes and pleasures have to decide their own, whether or not their outfits are according to the sensitivity of Islam?

Prohibition of squandering is also an example of this doctrine. In principle, extravagance has been decreed haraam. It is a variable matter which diverges from one person to another person, therefore its secondary description has not been provided. Hence its obligatory subsidiary details have been surrogated to the Muslims..$^{25}$ They have to decide while doing their daily course of business, whether or not their deeds fall in the slant of extravagance? Equability and moderation are the other examples of this principle. ${ }^{25}$

Similar is the case of repulsive and abominable animals. Primarily Allah (SWT) forbade the mankind from the consumption of disgusted animals but did not bestow compulsory secondary description. Therefore, the matter is SUB JUDICE to the jurists of this Ummah and they have diverse judgments in this regard.

Following hadith will enlighten this doctrine:

i. Narrated Khalid bin Al-Walid (RA) that he went with Allah's

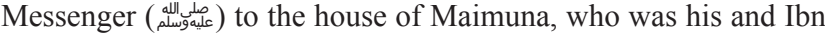
'Abbas' aunt. He found with her a roasted mastigure which her sister Hufaida bint Al-Harith had brought from Najd. Maimuna pre-

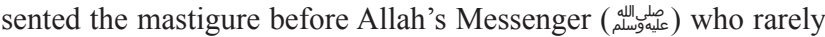
started eating any (unfamiliar) food before it was described and

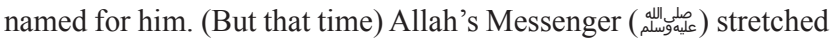
his hand towards the (meat of the) mastigure whereupon a lady from among those who were present, said, "You should inform

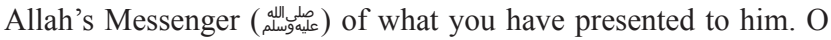

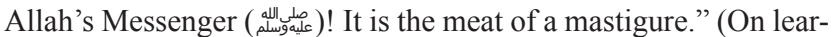

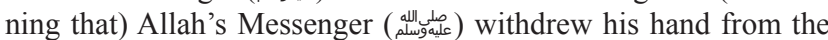
meat of the mastigure. Khalid bin Al-Walid said, "O Allah's Mes-

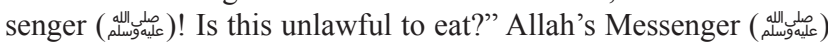
replied, "No, but it is not found in the land of my people, so I do not like it." Khalid said, "Then I pulled the mastigure (meat)

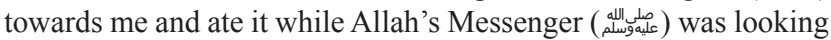
at me. ${ }^{23}$

Mastigure is actually a spiny-tailed lizard, which is now called dhab-lizard. Fundamentally it is herbivore, but occasionally the young members of this class consume insects and other small animals. In the above mentioned hadith when Prophet (PBUH) was informed about the roasted lizard which was presented before him, He pulled his hand back and when Khalid (RA) asked about its legal status, He replied, it is not haraam but I do not like it as it is not found in the land of my people. Then Khalid (RA) started eating the roosted lizard and the Messenger (PBUH) was looking at him with silence. There are two matters which can be derived from this hadith:

a. Prophet (PBUH) disliked the roasted lizard and disliking implies detestation (Sunan-at-Tirmidhi \#1790, Sunan- abu-Dawood \#3793). ${ }^{16}$

b. When Khalid (RA) started eating the lizard, besides, the Messenger (PBUH) did not like it, the Prophet (PBUH) kept on watching him with silence, hence empowered him to take his own decision.

Hereafter it is proven that detestation can be a variable matter and the decision whether a thing is repulsive or not, might be delegated to a person himself. Islam shows mercy and compassion with mankind by keeping silence in so many matters and by empowering the people to take their own decisions in such issues under the principles of jurisprudence. 


\section{Doctrine of adoption}

One of the objectives of Islam is to create and provide ease. The word "Islam" has been derived in Arabic from peace and harmony. ${ }^{23}$ Prophet (PBUH) preached brotherhood, compassion, mercy, mutual cooperation and trustworthiness all of his life. He (PBUH) started from himself and exhibited a model to his nation. Following hadiths are the crux of the religion in this context.

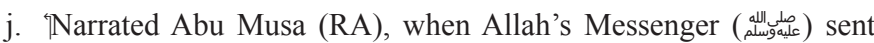
him and Mu'adh bin Jabal to Yemen, he said to them, "Facilitate things for the people (treat the people in the most agreeable way), and do not make things difficult for them, and give them glad tidings, and let them not have aversion (i.e. To make the people hate good deeds) and you should both work in cooperation and mutual understanding, obey each other. ${ }^{23}$

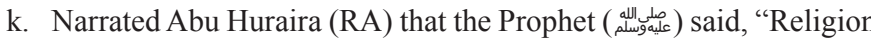
is very easy and whoever overburdens himself in his religion will not be able to continue in that way. So you should not be extremists, but try to be near to perfection and spread the good tidings that you will be rewarded and gain strength by worshipping in the mornings, the afternoons, and during the last hours of the nights". ${ }^{23}$

The above mentioned virtues and values were more required in the social and communal lives of Muslims as compared to their individual concerns; hence jurists inducted them in Islamic Jurisprudence and empowered them with the force of law. In this regard, Public Interest and Equity were included in jurisprudence as Secondary Sources of Law.

With the passage of time and with the evolution of jurisprudential laws, the jurists from various Schools of thought have developed a policy which is called Doctrine of Adoption. Under the principles of this doctrine the jurists from one school leave their own established opinion regarding an issue and adopt the view of other school for the sake of public interest. ${ }^{26}$ In the recent past the jurists from Hanafi' School have decreed in the favor of a woman who lost her husband completely for more than four years and neither she nor her and his own relatives did know anything about him, hence she allowed to marry anyone else. The limitation of four years was not the actual stance of the jurists of this school. Earlier they were in a view that the time span must be as long as the normal age duration of a generation. Later on they considered it hard and against the public interest, thus adopted the narrative of Maliki School which restricts four years for this purpose. This kind of adoption shall be exercised and exhibited by the knowledgeable scholars. Furthermore it shall not breach the vibrant principles of Quran and hadith.

The question escalates when the consumption of arthropods is discoursed in the context of this doctrine. Does the mentioned principle (Doctrine of Adoption) apply to their consumption? Yes, it can be applied after satisfying the said principles.

\section{Arthropods as alternative source of protein}

Consumption of sufficient amounts of dietary protein is fundamental to human growth and health. Dietary protein plays an important role in improving diet quality, promoting healthy aging, supporting bodyweight management, improving body composition, regulating appetite, and maintaining/increasing skeletal muscle mass in certain populations (i.e., elderly, athletes). Hence, protein consumption plays an important role in managing current public health issues such as obesity and age-related muscle loss. ${ }^{27}$ The fact has already been mentioned that the human population is increasing rapidly. It is now 7.6 billion and expected to reach 8.6 billion in 2030, 9.8billion in 2050 and 11.2 billion in $2100 .^{28}$ The rapid growth in population has started eclipsing the production of sufficient amounts of conventional animal-based, protein-dense foods to meet global dietary demands. ${ }^{1}$ Since the global population and per capita income are growing, the demand for animal-based, protein-rich food is expected to increase. Specifically, meat consumption per capita is expected to increase by $29 \%$ from $40.0 \mathrm{~kg}$ in the year 2013 to $51.5 \mathrm{~kg}$ in $2050 .{ }^{1} \mathrm{In}$ this scenario insects have been proposed as an alternative protein source that may contribute in meeting global demands for food protein.

The fact has been observed recently, particularly in North America and Europe, that the mass production of insects is being considered as an environmentally and economically viable protein-dense food source. Edible insects and insect-based food products, including insect powders, flours, protein bars, pasta, burgers, nuggets, and spreads, are currently available on the market for consumers. ${ }^{3}$ The protein content $(\mathrm{g} / 100 \mathrm{~g})$ of edible insects ranges from $7 \%$ to $48 \%$, which is comparable with the fresh-weight protein content of beef $(19 \%-26 \%)$, tilapia (16\%-19\%), and shrimp (13\%-27\%), additionally insects may possess environmental, economic, and agricultural advantages when compared with conventional livestock. ${ }^{27}$

Presently, insect-rearing facilities and farms are being developed in many countries. Insects produced in these facilities for human consumption are first cleaned, and then typically euthanized by freezedrying. Freeze-dried insects can be packaged and consumed whole or subjected to further processing in the form of roasting, cooling, and grinding to produce a fine powder or flour from whole insects prior to packaging. ${ }^{1}$ Some of the commercially raised and farmed insects for human consumption are given below in table 01 along with their protein content (Table 1).

Table I Various Insects Products with Protein Percentage

\begin{tabular}{|c|c|c|c|}
\hline Protein source & Company & Product & Protein\% \\
\hline Acheta domesticus & $\begin{array}{l}\text { ENTOMO } \\
\text { Farms }\end{array}$ & $\begin{array}{l}\text { Cricket Protein } \\
\text { Powder } 2050\end{array}$ & 65.0 \\
\hline Acheta domesticus & $\begin{array}{l}\text { Thailand } \\
\text { Unique }\end{array}$ & Cricket Flour & 57.5 \\
\hline Bombyx mori & $\begin{array}{l}\text { Thailand } \\
\text { Unique }\end{array}$ & Silkworm Flour & 53.8 \\
\hline Gryllus bimaculatus & $\begin{array}{l}\text { Thailand } \\
\text { Unique }\end{array}$ & Cricket Flour & 59.4 \\
\hline Locusta migratoria & $\begin{array}{l}\text { Thailand } \\
\text { Unique }\end{array}$ & Locust Flour & 69.4 \\
\hline Tenebrio molitor & $\begin{array}{l}\text { ENTOMO } \\
\text { Farms }\end{array}$ & $\begin{array}{l}\text { Mealworm Protein } \\
\text { Powder } 2050\end{array}$ & 58.1 \\
\hline $\begin{array}{l}\text { Alphitobius } \\
\text { iaperinus }\end{array}$ & $\begin{array}{l}\text { Kreca Ento- } \\
\text { Food BV }\end{array}$ & $\begin{array}{l}\text { EntoPure sports } \\
\text { protein concentrate }\end{array}$ & 70.0 \\
\hline
\end{tabular}

\section{Legal guidelines on insect consumption}

Consumption of insects is traditional in some parts of the world, while in others it is a new phenomenon and as a result it is rarely regulated in the countries where these tiny creatures have been added recently to the human food. ${ }^{5}$ This leads to public institutions like food agencies, customs and health departments often finding themselves helpless in the face of new product development based on processed insects. As per the legal status of insect consumption is concerned there are four legal trends found in the world: 
a. The Anglo-Saxon countries consider the U.S. FDA's position enough to allow the marketing.

b. The non-English speaking western countries particularly the European Union feels to have proper rules prior to allowing marketing.

c. In some parts of the East where consuming insects is traditional but rarely packaged and exported or imported.

d. In Muslim countries where eating and drinking is a religious matter, the only insect whose consumption is legal is the locust.

e. Following are some important countries along with their legal position on insect consumption.

United States of America (USA): As mentioned earlier there is no specific set of standards for edible insects in America. In general, for insects to be allowed for marketing they must have been bred for human consumption. Good manufacturing practice certificates and bacteriological tests are also required prior to marketing. Furthermore, the label on the product must include the common and the insect scientific name in addition to note on the potential risk of allergy. ${ }^{5}$

European Union: The European Parliament and the European food safety agency (EFSA) categorize insect foods as novel foods, hence, subject to lengthy approval process prior to marketing. There are some countries like, Belgium, Netherlands and Denmark; they do not accept this interpretation, therefore they need not the lengthy approval process for marketing. However in a meeting in October 2015, the European parliament simplified the steps and reduced the timings (sometimes three years) for the approval of edible insects. The new law has taken the cognizance from the first January of the current year (2018). EFSA has stated that all insect products for human consumption will be considered a 'Novel Food' and must be submitted for Novel Food approval by 2018 , with a 2 -year transition period allowing already approved products to stay on the market until $2020 .{ }^{29}$

Britain: Unlike the European Union the Britain has the favorable stance on the sale, consumption and import of edible insects. Since Britain does not recognize it as novel foods, therefore they don't apply the lengthy process of approval. ${ }^{5}$ With the occurrence of Brexit, it is unclear whether the UK will still follow the EFSA ruling or proceed with its own approval process under the Food Standards Agency (FSA), where decisions would presumably no longer need to be ratified by EFSA, perhaps giving more legislative freedom. ${ }^{29}$

South East Asian Countries: As discussed that there are some parts of the world where insect consumption is traditional. The countries like Thailand, South Korea and China are the vibrant examples where this tradition is very rich. Therefore, in this part of the world there had been no regulatory hurdles to their production, marketing and consumption. However, Thailand, the world's largest cricket breeder is now working on their first breeding guidelines..$^{29}$ The only insect which is included in the guidelines by the Health Ministry in China is the silkworm. China is world's largest producer of silk and breeder of silkworms which are also exported for consumption purpose. Furthermore, the South Korean Food and Drug Administration has classified the cricket and mealworm as normal food without any restriction. ${ }^{5}$

Muslim countries: In Islam consumption is subjected to the guidelines approved by Quran and sayings of the Prophet Muhammad (PBUH). Muslims are traditionally meet lovers; therefore domesticated animals like cattle, goat, sheep etc. have been their main sources of food, whereas, eating insects has never been their tradition over the centuries. Locust is the only insect whose consumption is unanimously allowed amongst all the schools of thought. Apart from it, diversity is found in the opinions of various Islamic sects. Regarding insects, the latest issue arisen to the faces of Islamic Scholars is the natural carmine dye (E120) derived from an insect which is called cochineal. It is used in various food and non-food items. ${ }^{30}$ The paper aims to elaborate on this issue in the coming pages.

\section{Cochineal}

It is actually a scale insect, from which the natural dye carmine (E120) is derived, thus used in food, cosmetic and pharmaceutical industries. The bigger in shape is male while smaller is female. This insect is found in Mexico and South America. Central America originated the carmine dye in 15th Century. Hence it was used to color the fabrics. That was colonial, pre-Industrial revolution age. Later on in $19^{\text {th }}$ Century when synthetic colors were invented, the use of natural dye gradually vanished. After a long time health fears over artificial food additives have restored the practice of carmine dye. Hereafter voices are being raised by the Hanafi' and Imamia Schools as insects are considered non-halal among them. To resolve the matter under the principles of doctrine of adoption the questions shall be put firstly to the Muslim Food Scientists. Whether or not this color is in the best interest of the public? While answering this question some of them are of the view that since carmine is from the chemical class called ANTHRAQUINONES, hence it is very beneficial for the better management of diabetes, blood pressure and cancer and approved by the US FDA since 1969. ${ }^{31}$ Therefore, more clinical studies are required that can it be used instead of medicine? Furthermore, is it necessary to use this dye and is it healthier than the artificial additives? If so, then secondly the matter shall be referred to the scholars. After detailed discussion they may replace their established opinion with that of the viewpoint of Imam Malik to render the cochineal color halal (Figure 6).

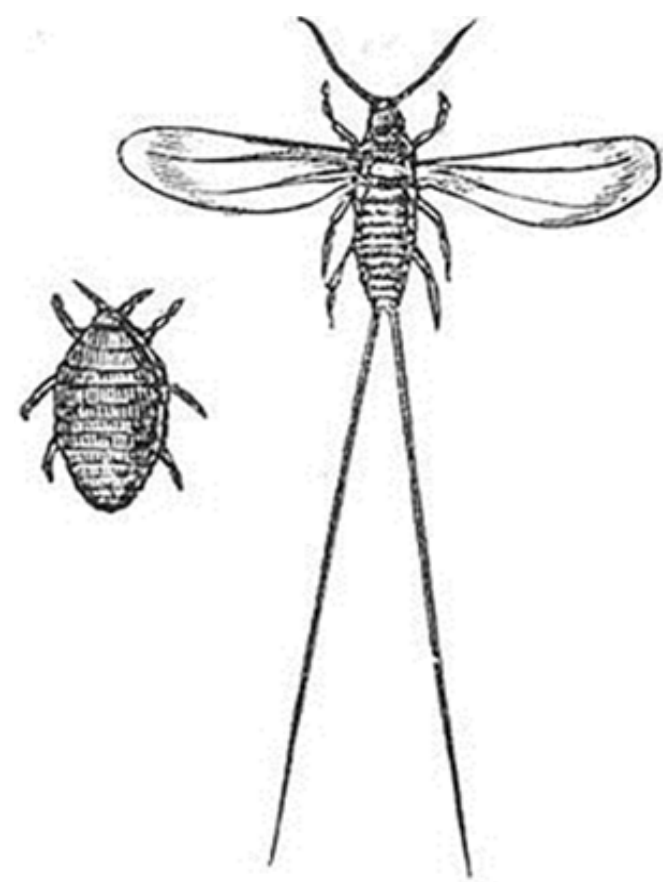

Figure 6 Cochineal. 
Production of carmine dye: Carmine is known by various names such as Cochineal, Cochineal Extract, Crimson Lake, C.I. 75470, E120 and Natural Red. Commercial production of carmine is a laborious procedure. Firstly, the cochineal insects are grown on cactus plants for around three months. Picking these insects from the cacti is a very delicate process. ${ }^{31}$ They are carefully brushed from the plants and put into bags. At the production house, these insects are placed in very hot water or kept under harsh sunlight. One pound of Cochineal is produced by squeezing 70,000 insects. One cochineal insect contains around 18 to $20 \%$ of carminic acid stored in their abdomen. Their abdomen also houses fertilized eggs. When all the anatomical fragments (except eggs) get completely dry, they are grounded and cooked to extract optimum amount of red pigment. Methods of killing and drying the cochineals vary widely. Insects may be killed in boiling water or by drying in the sun or in ovens. Modern operations use carefully controlled heating methods to ensure uniform quality, although oven-killed and sun-dried material is still popular in less developed areas. ${ }^{32}$

The extraction solvent may be water or an aqueous ethanol solution, either of which is made alkaline with sodium or potassium hydroxide or carbonate, or ammonium hydroxide. At least one process, apparently borrowed from ancient production methods for kermes, uses water acidified with acetic acid. The extraction liquor may be dried or sold as a liquid, typically under the names cochineal or cochineal extract, respectively. It contains carminic acid, soluble proteins, carbohydrates and other biological molecules from the insects, as well as various ionic salts from the extraction process. ${ }^{32}$

As it has been known earlier that Maliki School of thought permits the consumption of non-hazardous insects, the above mentioned method of extracting the carmine dye from exoskeleton of cochineal insect is absolutely in line with the injunctions of this school. The Maliki scholars ruled that it is permissible to eat insects with the condition of being dead with any means. As for locusts their scholars debated over it, as some believed that locusts do not need to be slaughtered and it is permissible to eat when found dead. ${ }^{21}$ Other scholars found it necessary to slaughter them in ways which would normally lead to its death such as cutting off its head or poking it with thorns or pins or throwing it in fire or hot water. ${ }^{22}$

There are some other methods for the production of carmine dye is in use, in which egg white, fish glue, or gelatin is sometimes added before the precipitation. In such cases for halal production of carmine dye, egg white shall be of halal bird as well as gelatin shall be halal certified. $^{32}$

The quality of carmine is affected by the temperature and the degree of illumination during its preparation, sunlight being requisite for the production of a brilliant hue. It also differs according to the amount of alumina present in it. It is sometimes adulterated with cinnabar, starch and other materials; from these, the carmine can be separated by dissolving it in ammonia. Good carmine should crumble readily between the fingers when dry.

\section{Industrial uses of carmine dye}

Carmine dye is used in the following major industries:

a. Food Industry-Frozen fish, meat, etc.

b. Beverage Industry-Soft drinks, fruit drinks, energy drinks, etc. c. Alcoholic Beverages-Products with low $\mathrm{pH}$ requiring red or orange tones.

d. Dairy Industry-Yogurts, ice cream and dairy based beverages

e. Confections-Candy, fillings, syrups, chewing gum, etc.

f. Fruit Preparations-Canned fruits such as cherries, Jams, Pulp, etc.

g. Cosmetic Industry-Dispersions close to eye area, eye shadows, lipsticks, etc.

h. Others-Ketchup, powdered drinks, dehydrated soups, canned soups, etc.

i. Pharmaceutical Industry-To color pills and ointments.

j. Textile Industry-To color the fabrics.

Carmine is also used in the manufacture of artificial flowers, paints and crimson ink. A bright red dye and the stain carmine used in microbiology is often made from the carmine extract.

\section{Allergy hazard}

It is essential to know that carmine dye has been known to cause rarely severe allergic reactions and anaphylactic shock in some people. Following are some of the case studies.

\section{Case study}

A non-smoking, non-atopic 18-year-old man who had worked for 1 year weighing batches of carmine in the cosmetics industry was assessed for occupational asthma. Alterations in lung function and increased airway responsiveness to histamine were recorded after challenge in a chamber with lactose powder containing $3 \%$ carmine. The patient was unaware of the nature of the challenge, as lactose powder colored with amaranth was used in the control trial. ${ }^{33,34}$

A 35-year-old man who had developed asthma and rhino conjunctivitis after handling carmine at work reported an asthmatic episode after ingestion of red-colored sweet containing carmine. The result of a double-blind oral challenge with E120 was positive. ${ }^{35}$

Although concerns over hazards from allergic reactions have been asserted but since these are rare, therefore the U.S. FDA and the European Commission's directives governing food additives in general and food dyes in particular have not banned the use of carmine and state that there found no evidence of a "significant hazard" to the general population. ${ }^{36,37}$

\section{Halal standards guidelines on the consumption of arthropods}

Halal operations are carried out under the principles of numerous Halal Standards all around the globe. Several Islamic Countries have developed their own in addition to the SMIIC. Each and every standard has appropriate guidelines for Halal Certification Bodies. Following are some of the glimpses regarding the consumption of arthropods: ${ }^{18,38}$

a. SMIIC Standard (Clause\#5.1.1.2) states that, venomous animals such as scorpion, centipede and wasps are non-Halal, as well as the repulsive animals such as insects and those that are forbidden to be killed, like honeybee and hoopoe.

b. Pakistan Standard (PS 3733, Clause\#4.1.1.3) proclaims absolutely the same as mentioned in SMIIC Standard. 
c. Malaysian Standard (MS 1500:2009, Clause\#3.5.1.1.1) repeats the same as stated in SMIIC Standard but narrates flies and lice instead of insects.

d. Singapore Standard (MUIS-HC-S001, Clause A.5.2) considers non-poisonous land crabs as Halal.

e. MUI (Indonesia HAS 23201) Halal Standard on Materials (Material \#10,11 and 13) professes that cochineal color is Halal as well as the crabs and worms, if not poisonous.

f. UAE Standard (UAE.S 2055-1:2015, Annex 1) proclaims that Scorpions and all types of insects, worms and animals prohibited to be killed by rules and the like such as ants, bees, woodpeckers and hoopoes, except for locusts and unavoidable bee parts falling in honey.

All the Halal Standards either mentioned above or not, are in agreement that poisonous and repulsive animals are haraam. There is no ambiguity in poison as it is an apparent factor of prohibition, but the opinions are diverse and uncertain about repulsiveness. Some of the standards consider cochineal color halal, which is derived from an insect, while the other standards consider it haraam as they contemplate insects repulsive. Some standards narrate land crabs halal, while the others might include them in repulsive animals. The matter is alike regarding worms as well. The core of the matter is that Allah (SWT) and Prophet Muhammad (PBUH) did not provide conclusive and exclusive details of abominable and repulsive animals as (They) conveyed about the other prohibited animals, hence this issue depends upon the juristic opinions which are diverse (Table 2). ${ }^{24}$

Table 2 Countries with their Halal Acceptance Status of EI 20

$\begin{array}{ll}\text { Malaysia } & \text { EI20 Allowed } \\ \text { Indonesia } & \text { EI20 Allowed } \\ \text { UAE and Gulf } & \text { EI20 Not Allowed } \\ \text { Pakistan } & \text { EI20 Not Allowed } \\ \text { Turkey } & \text { EI20 Allowed } \\ \text { Singapore } & \text { EI20 Allowed } \\ \text { China } & \text { EI20 Allowed } \\ \text { America and Europe } & \text { EI20 Allowed } \\ \text { Tunisia } & \text { EI20 Allowed } \\ \text { Algeria } & \text { EI20 Allowed } \\ \text { Morocco } & \text { EI20 Allowed } \\ \text { Iran } & \text { EI20 Not Allowed }\end{array}$

\section{Halal certification bodies certifying E I 20:}

a. IFANCA (Islamic Food and Nutrition Council of America)

b. HFCE (Halal Food Council of Europe)

c. MUI (Majlis-e-Ulama-e-Indonesia)

d. JAKIIM (Department of Islamic Development Malaysia)

United States Food and Drug Administration (FDA) guidelines for E120: The Food and Drug Administration (FDA or USFDA) is a federal agency of the United States Department of Health and Human
Services, one of the United States federal executive departments. The FDA is responsible for protecting and promoting public health through the control and supervision of food safety, tobacco products, dietary supplements, prescription and over-the-counter pharmaceutical drugs (medications), vaccines, biopharmaceuticals, blood transfusions, medical devices, electromagnetic radiation emitting devices (ERED), cosmetics, and animal foods \& feed and veterinary products. ${ }^{36}$

In January 2006, the United States Food and Drug Administration (FDA) evaluated a proposal that would require food products containing carmine to list it by name on the ingredient label. On January 5, 2009, the Food and Drug Administration (FDA) published a final rule in the Federal Register that amended its regulations to require the declaration by name of the color additives cochineal extract and carmine on the label of all food and cosmetic products in the United States (74 FR 207). The final rule is effective on January 5, 2011, although FDA encourages manufacturers to have new labels printed that are in compliance with the new requirements so they may be used as soon as current inventories are exhausted to ensure a smooth and timely changeover. FDA has prepared this Small Entity Compliance Guide in accordance with section 212 of the Small Business Regulatory Enforcement Fairness Act (Public Law 104121). This guidance document restates in plain language the legal requirements of the January 5, 2009 final rule set forth in 21 CFR parts 73 and 101 concerning the requirement for the declaration by name of the color additives cochineal extract and carmine on the label of all food and cosmetic products in the United States. These regulations are binding and have the full force and effect of law. ${ }^{36}$ Although concerns over hazards from allergic reactions have been asserted, ${ }^{16}$ the FDA has not banned the use of carmine and states it found no evidence of a "significant hazard" to the general population. ${ }^{36}$

European Union guidelines on E120: In the European Union, the use of carmine in foods is regulated under the European Commission's directives governing food additives in general and food dyes in particular and listed under the names Cochineal, Carmine acid, Carmines and Natural Red 4 as additive E 120 in the list of EUapproved food additives. The directive governing food dyes approves the use of carmine for certain groups of foods only and specifies a maximum amount which is permitted or restricts it to the quantum satis. The EU-Directive 2000/13/EC on food labeling mandates that carmines (like all food additives) must be included in the list of ingredients of a food product with its additive category and listed name or additive number, that is either as Food color carmines or as Food color E 120 in the local language(s) of the market(s) the product is sold in EC. ${ }^{39}$ The directive governing food dyes approves the use of carmine for certain groups of foods only and specifies a maximum amount which is permitted or restricts it to the quantum satis. The list of approved food stuff can be found in annex III of the following link

http://www.fsai.ie/uploadedFiles/European_Parliament_and Council_Directive 94 36_EC.pdf

\section{Conclusion}

Since ARTHROPODA is the biggest phylum which contains more than eighty percent of the known animals, therefore all of them shall not be deemed repulsive as there are numerous attractive and eye-catching species among them. It is against the Divine Innovative Philosophy to declare such a big number of living organisms repulsive due to the presence of some disgusted species. It has been observed over the centuries that Muslims do not domesticate these tiny creatures for 
consumption, hence they feel discomfort with them but awkwardness does not mount to detestation in every case. Prohibition is categorized as Makrooh-e-Tenzeehi, Makrooh-e-Tehreemi and Haraam. Therefore every forbidden thing or act shall not mount to apex category (Haraam), it might be disallowed as Tenzeehi or Tehreemi. Furthermore, Haraam can only be derived from definitive verse or hadith. Any restriction that is imposed by speculative verse or hadith shall mount to Makrooh-e-Tenzeehi or Tehreemi. Speculative verses and hadiths are the actual domain of differentiation which is found among the various Schools of thought and is indeed the beauty of Islam. The verse $(7: 157)$ that has been mentioned with regard to the prohibition of arthropods is speculative in the absence of conclusive and exclusive details of abominableness, therefore according to this verse, arthropods as a phylum shall not be deemed Haraam (apex category) due to detestation unless any of its members falls under any other definitive verse or hadith, if found. In such case that specific animal shall be rendered Haraam. If repulsiveness is not proven by the definitive verse or hadith but rather through speculative verse or hadith then prohibition shall mount to Makrooh-e-Tehreemi or Tenzeehi depending upon the nature of text. Furthermore, in such case detestation might be a variable matter and can be enlisted under the doctrine of silence where subsidiary mandatory injunctions are not provided, hence jurists are empowered to decide their own under the principles of jurisprudence. Under the doctrine of adoption Hanafi', Shafi'I and Imamia Schools can replace their established opinions with the viewpoint of Maliki School to render the non-poisonous/hazardous insects specifically bred for human consumption as alternative source of protein, and cochineal color Halal if the required conditions are fulfilled.

\section{Acknowledgements}

None.

\section{Conflict of interest}

Author declares that there is none of the conflicts.

\section{References}

1. Wu G, Fanzo J, Miller DD, et al. Production and supply of high-quality food protein for human consumption: sustainability, challenges, and innovations. Ann N Y Acad Sci. 2014;1321:1-19.

2. Dossey AT, Tatum JT, Mcgil WL. Chapter 5-Modern Insect-Based Food Industry: Current Status, Insect Processing Technology, and recommendations moving forward. Insects as sustainable food ingredients. 2016:113-152.

3. Akhtar $Y$, Isman MB. Insects as an alternative protein source. Proteins in Food Processing. 2017:263-288.

4. Raheem SFU, Demirci MN. Assuring Tayyib from a food safety perspective in Halal food sector: a conceptual framework. MOJ Food Process Technol. 2018;6(2): 170-179.

5. Reverberi M. Exploring the legal status of edible insects around the world. 2017.

6. Hegna TA. The correct authorship of the taxon name 'Arthropoda'. 2013.

7. Thanukos A. The Arthropod Story. Berkeley: University of California; 2008.

8. Lane RP. Introduction to the arthropods. In: Lane RP, Crosskey RW, editors. Medical Insects and Arachnids. Dordrecht: Springer; 1993

9. Mirza MA. Zoology, Ilmi Kitabkhana, Urdu Bazar Lahore. 2014.
10. Anderson RF. Forest and Shade Tree Entomology. Soil Science; 1961;91(6): 413.

11. Petr H. 25 Stunningly Beautiful Insects. 2016.

12. Sobczyk T. Psychidae: World Catalogue of Insects 10. Apollo Books Stenstrup; 2011. $467 \mathrm{p}$.

13. Harvey Alan, MartinWJ, Wetzer Regina. Phylum Arthropoda: Crustacea. Academic Press; 2001:337-369.

14. Stoev Pavel, Zapparoli Marzio, Golovatch Sergei, et al. Myriapods (Myriapoda). BioRisk; 2010;4:97-130.

15. Coddington Jonathan, Giribet Gonzalo, Harvey Mark. Arachnida. Assembling the Tree of Life; 2004;296-318.

16. Abu Dawood S. n.d. Sunan abu Dawood. Beroot: Maktabat ul Asria.

17. Zeedan AK. n.d. Alwajeez Fi Usool-al-Fiqh. Lahore: Maktabah Rahmaniah.

18. Zhang Zhi-Qiang. Phylum Arthropoda. In: Zhang ZQ, editor. Animal Biodiversity: An Outline of Higher-level Classification and Survey of Taxonomic Richness. Zootaxa .2013;3701(1):17-26.

19. Kasani AA. Al Badai-ul-Snai, Maktabah Rasheediah. Southern California: Albalagh Book Store; 1996.

20. Sistani AH. n.d. Al-istifta't.

21. Navavi M. n.d. Al majmoo. Bruit Publication.

22. Rushd I. n.d. Bidayat-ul-Mujtahid. Daar ul Hadith Publication.

23. Rushd I. n.d. Al Bayan w Al Tahsil. Dar al Gharb al Islami publishing house.

24. Al Bukhari M. 1422 Hijri. Sahih al Bukhari. Beroot: Daar ul Taqwa al Nijah.

25. Raheem SFU. Consumption of Arthropods. Halalfocus.net; 2017.

26. Zahid M. n.d. Ashraf-ul-Tawzeeh. Faisalabad: Maktabah Imdadiah.

27. Thanvi AA. n.d. Heelah Najizah. Karachi: Daar-ul-Ishaat.

28. Churchward-Venne TA, Pinckaers PJM, Van Loon JJA, et al. Consideration of insects as a source of dietary protein for human consumption. Nutrition Reviews. 2017;75(12): 1035-1045.

29. United Nations. Department of Economics and Social Affairs. New York; 2017.

30. Dobermann D, Swift JA, Field LM. Opportunities and hurdles of edible insects for food and feed. Nutrition Bulletin. 2017;42(4): 293-308.

31. Galaffu N, Bortlic K, Michel M. An industry perspective on natural food colour stability. Switzerland: Natural Products. Nestlé Research Centre, Lausanne; 2015.

32. Cai Y, Qiu R. Hypoglycemic activity of two anthraquinone derivatives from Juncus setchuensis Buchen. Int J Clin Exp Med. 2016;9(10):19664 19672.

33. Dapson R. The history, chemistry and modes of action of carmine and related dyes. Biotechnic \& Histochemistry. 2007;82(4-5):173-187.

34. Durham SR, Graneek BJ, Hawkins R, et al. The temporal relationship between increases in airway responsiveness to histamine and late asthmatic responses induced by occupational agents. J Allergy Clin Immunol. 1987;79(2):398-406.

35. Graneek BJ, Durham SR, Newman Taylor AJ. Late asthmatic reactions and changes in histamine responsiveness provoked by occupational agents. Bull Eur Physiopathol Respir. 1987; 23(6):577-581. 
36. Acero S, Tabar AI, Alvarez MJ, et al. Occupational asthma and food allergy due to carmine. Allergy. 1998;53(9):897-901.

37. Food and Drug Administration (FDA) of United States of America.

38. European Union Guidelines on E120. Official journal of European communities. 1994:1-17.
39. Chakravarthy K, Akshay Kumar. New Horizons in Insect Science: Towards Sustainable Pest Management. Springer. 2015. 